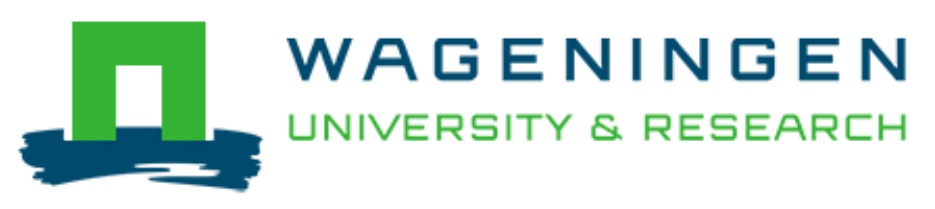

The interplay between regulatory focus and temporal distance in the health context

Berezowska, A., Fischer, A. R. H., \& van Trijp, H. C. M.

This article is made publically available in the institutional repository of Wageningen University and Research, under article $25 \mathrm{fa}$ of the Dutch Copyright Act, also known as the Amendment Taverne.

Article $25 \mathrm{fa}$ states that the author of a short scientific work funded either wholly or partially by Dutch public funds is entitled to make that work publicly available for no consideration following a reasonable period of time after the work was first published, provided that clear reference is made to the source of the first publication of the work.

For questions regarding the public availability of this article, please contact openscience.library@wur.nl.

Please cite this publication as follows:

Berezowska, A., Fischer, A. R. H., \& van Trijp, H. C. M. (2018). The interplay between regulatory focus and temporal distance in the health context. British Journal of Health Psychology, 23(1), 22-37. DOI: 10.1111/bjhp.12272

You can download the published version at:

https://doi.org/10.1111/bjhp.12272 


\title{
The interplay between regulatory focus and temporal distance in the health context
}

\author{
Aleksandra Berezowska*, Arnout R. H. Fischer and \\ Hans C. M. van Trijp \\ Marketing and Consumer Behaviour Group, Department of Social Sciences, \\ Wageningen University and Research Centre, The Netherlands
}

Objectives. This study identifies how the interaction between temporal distance, regulatory focus, and framing of health outcomes affects individuals' intention to adopt a personalized nutrition service.

Design. A 2 (temporal distance: immediate health outcomes vs. delayed health outcomes) $\times 2$ (regulatory focus: prevention vs. promotion) $\times 2$ (health outcome framing: illness prevention vs. health promotion) full-factorial between-subjects design.

Methods. In two experiments with samples of 236 and 242 students, regulatory focus was manipulated by asking participants to describe which academic outcomes they want to either achieve or prevent and how they aim to do this. Temporal distance and health outcome framing were manipulated by modifying descriptions of personalized nutrition services. To study the process through which temporal distance, regulatory focus, and health outcome framing affect adoption intention, measures of perceived privacy risk and perceived personalization benefit were included as mediators.

Results. The interaction between temporal distance and regulatory focus had a significant effect on adoption intention, perceived privacy risk, and perceived personalization benefit. For prevention-focused individuals' adoption intention was higher, perceived personalization benefit was higher, and perceived privacy risk was lower when health outcomes were immediate instead of delayed. These effects were not significant for promotion-focused individuals. Health outcome framing affected the interaction between temporal distance and regulatory focus, but only in Study I. Only perceived personalization benefit served as a mediator.

Conclusion. Tailoring temporal distance to individuals' regulatory focus increases adoption intention for personalized nutrition advice.

\section{Statement of contribution}

What is already known on this subject?

- Intention to adopt dietary recommendations results from a cognitive decision-making process.

- Regulatory focus and temporal distance are relevant for the adoption of dietary recommendations.

- Temporal distance and regulatory focus are interrelated.

*Correspondence should be addressed to Aleksandra Berezowska, Marketing and Consumer Behaviour Group, Department of Social Sciences, Wageningen University and Research Centre, Hollandseweg I, 6706 KN Wageningen, The Netherlands (email: aleksandraberezowska@hotmail.com). 
What does this study add?

- The interaction between temporal distance and regulatory focus affects adoption intention.

- Interaction between temporal distance and regulatory focus moderates the cognitive process that drives adoption.

Although eating healthily is important for current and future health, it remains a challenge to many (Bouwman, te Molder, Koelen, \& van Woerkum, 2009). Following healthy eating recommendations often comes at the cost of eliminating foods that are immediately gratifying, but in the long term unhealthy. Considering temporal discounting, long-term health benefits are likely to be perceived as less valuable in the present (Story, Vlaev, Seymour, Darzi, \& Dolan, 2014), which may lead to a situation where the perceived benefits of adhering to dietary recommendations do not outweigh the perceived costs (Chapman \& Elstein, 1995). To increase benefit perceptions, dietary recommendations are becoming more and more individualized, a field known as personalized nutrition (Gibney \& Walsh, 2013). Using consumers' personal health information, personalized nutrition services tailor dietary recommendations to individual consumer needs (Ronteltap, Van Trijp, Berezowska, \& Goossens, 2013). Service design may maximize consumers' intention to adopt personalized nutrition services (Berezowska et al., 2014). Under different regulatory foci (individuals in a promotion or prevention state), the present paper explores two of such design factors: (1) temporal distance (immediate vs. long-term costs and health benefits); and (2) framing of health outcomes (illness prevention vs. health promotion).

Individuals' intention to adopt a personalized nutrition service is affected by the specific health goal that individuals want to accomplish. Individuals engage in health behaviour to prevent illness and/or to promote health (Gomez, Borges, \& Pechmann, 2013). Which of the two health goals is most salient relates to an individual's regulatory orientation or regulatory focus (Higgins, 1997). In the case of a prevention focus, goals are driven by the need for safety and security, while in the case of a promotion focus, goals result from the need for accomplishment and advancement (Higgins, 2000). Consequently, prevention-focused individuals are likely to be oriented towards the prevention of illness, whereas promotionfocused individuals may be more oriented towards the promotion of health. Regulatory focus is a so-called trait with state properties (e.g., Motyka et al., 2014), which implies that individuals are chronically more focussed on either prevention or promotion (i.e., the personality trait), but that their focus may shift dependent on the specific situation or context (i.e., situation-dependent state). Hence, the effect of regulatory focus on adoption intention is likely to depend on both one's personality and the situation.

Prior studies suggest that temporal distance and regulatory focus are interrelated (Mogilner, Aaker, \& Pennington, 2008; Pennington \& Roese, 2003). More specifically, individuals in a promotion-focused state perceive goals that should be accomplished in the distant future as more relevant than goals that should be accomplished in the near future (Steinhart, Mazursky, \& Kamins, 2013). In the case of a prevention focus, however, goals in the near future are seen as more relevant than goals in the distant future. Similarly, goals of promotion-focused individuals lie further in the future than goals of prevention-focused individuals (Pennington \& Roese, 2003). Considering that both regulatory focus and temporal distance are relevant for the adoption of personalized nutrition services, it may be that individuals' adoption intention increases when the temporal distance of such service fits one's regulatory focus. Currently, evidence for such effect is, however, lacking. Hence, we suggest that: 
Hypothesis la: For prevention-focused individuals, intention to adopt a personalized nutrition service is higher when outcomes of the advice are presented as immediate rather than delayed.

Hypothesis Ib: For promotion-focused individuals, intention to adopt a personalized nutrition service is higher when outcomes of the advice are presented as delayed rather than immediate.

The adoption of a personalized nutrition service is likely to result from cognitive decisionmaking (Berezowska, Fischer, Ronteltap, Van der Lans, \& Van Trijp, 2015). Currently, little is known about the cognitive process that mediates the effect of temporal distance, regulatory focus, and their interplay on adoption intention. Such understanding may provide insights for designing successful personalized nutrition services. Perceptions of risk and benefit are two cognitive factors that may mediate the effect of the interplay between regulatory focus and temporal distance on goal attainment, as individuals' intention to adopt a personalized nutrition service is determined by their attitude (Poínhos et al., 2014), of which risk and benefit perceptions are vital components (Berezowska et al., 2014, 2015; Ronteltap, van Trijp, \& Renes, 2007). Risk and benefit perceptions depend on whether the outcomes of their actions concern the present or the future (Eyal, Liberman, Trope, \& Walther, 2004). More specifically, as temporal distance increases (i.e., behavioural outcomes lie further in the future) risk perceptions decrease and benefit perceptions increase. Furthermore, it seems that prevention-focused individuals are more likely to focus on risks, while promotion-focused individuals are likely to focus on benefits (Wallace \& Chen, 2006; Werth $\&$ Forster, 2007). Based on these findings, the effect of the interplay between temporal distance and regulatory focus on adoption intention is considered to be (at least partly) mediated through individuals' risk and benefit perceptions. We therefore hypothesize that:

Hypothesis 2: The effect of temporal distance and health outcome framing on adoption intention is mediated by perceived personalization benefit.

Hypothesis 3: The effect of temporal distance and health outcome framing on adoption intention is mediated by perceived privacy risk.

Hypothesis 4a: In the case of prevention-focused individuals, perceptions of personalization benefit are higher when health outcomes are immediate rather than delayed.

Hypothesis 4b: In the case of promotion-focused individuals, perceptions of personalization benefit are higher when health outcomes are delayed rather than immediate.

Hypothesis 5a: In the case of prevention-focused individuals, perceptions of privacy risk are lower when health outcomes are immediate rather than delayed.

Hypothesis 5b: In the case of promotion-focused individuals, perceptions of privacy risk are lower when health outcomes are delayed rather than immediate. 
Individuals' intention to adopt a personalized nutrition service may differ depending on whether the recommendations are framed in terms of gains or non-losses. Promotionfocused individuals are more likely to adopt health interventions that are framed in terms of gains and prevention-focussed individuals are more likely to adopt health interventions that are framed in terms of non-losses (Cesario, Grant, \& Higgins, 2004; Hong \& Lee, 2008; Spiegel, Grant-Pillow, \& Higgins, 2004). The evidence for this regulatory fit effect is, however, mixed as shown by Ludolph and Schulz (2015). To identify whether framing affects the interaction between temporal distance and regulatory focus, this study frames health outcomes in terms of health promotion (i.e., gain) or illness prevention (i.e., nonloss), hypothesizing:

Hypothesis 6: The interaction between temporal distance and regulatory focus is moderated by the framing of provided health outcomes.

\section{STUDY I}

\section{Methods}

\section{Design and sample}

The study followed a 2 (temporal distance: immediate vs. delayed health outcomes) $\times 2$ (health outcome framing: prevent illness vs. promote health) $\times 2$ (regulatory focus: prevention vs. promotion) full-factorial between-subjects design. Participants were 236 Dutch (under) graduate students from different disciplines. A power calculation conducted to determine sample size that allows for the identification of medium to large effects (partial $\eta^{2}=.25$ following Cohen, 1992) for the overall model suggested 30 participants per group. ${ }^{1}$ The age of the participants ranged from 17 to $28(M=21.7$, $S D=1.92), 34 \%$ of the sample was male. Data were collected late spring 2015 .

\section{Manipulations, stimuli, and measures versus}

Temporal distance and health outcome framing were manipulated by creating flyers that represented fictitious personalized nutrition services. Temporal distance was manipulated by making the flyer state that engaging with the service provides health outcomes for the upcoming summer (immediate health outcomes) or after one has turned 50 years old (delayed health outcomes). Health outcome framing was manipulated by varying health outcomes that were provided by a personalized nutrition service. In case of the prevent illness frame, the service offered to prevent fatigue; in the case of the promote health frame, the service offered to increase energy levels this summer or be in great shape after turning 50 years old (detailed flyer content is provided in Appendix A). To make sure that temporal distance and health outcome framing manipulations indeed induced perceptions of immediate versus delayed health outcomes and illness prevention versus health promotion, flyer content was pilot tested during several consecutive tests ( $n=10$, per pilot test). Using a 5point scale ranging from very unrealistic to very realistic, we also assessed whether flyer content was perceived as sufficiently real. Flyers were piloted and revised until participants considered both the manipulations and flyer realness as good $(M=3.5$, $S D=0.85$ ). To control for flyer layout, layout application was counterbalanced (Appendix B). To elicit benefit perceptions, the flyers stated that personalized

\footnotetext{
${ }^{1}$ Corresponds to minimum effect sizes of 0.18 for main and interaction effects; calculation conducted with G*power.
} 
nutrition advice was provided by a qualified dietitian and based on innovative techniques that significantly increased effectiveness when compared to regular dietary advice. To prompt perceptions of privacy risk flyers stated that one of the innovative techniques was DNA analysis and that nutrition advice was refunded by one's health insurance company, which suggests that an insurer may access one's genetic profile and use it for purposes other than initially intended. The prompts to induce personalization benefit and privacy risk were derived from extensive focus group discussions reported in Berezowska et al. (2014). As this study aimed to investigate the cognitive process that mediates the effect of temporal distance and regulatory focus on adoption intention, rather than establishing individuals' risk and benefit perceptions, no in-depth explanation of personalized nutrition was provided.

Regulatory focus was manipulated with the procedure established by Lockwood, Jordan, and Kunda (2002). To induce promotion focus, participants were asked to write a short statement on which positive academic outcomes they wanted to achieve and how they wanted to achieve those outcomes. To induce prevention focus, participants were asked to write a short statement on which negative academic outcomes they wanted to prevent and how they wanted to prevent those outcomes.

Adoption intention was measured on a reliable 7-point scale ranging from strongly disagree to strongly agree using three items (Cronbach's alpha $=.89$ ): (1) I would consider using this service; (2) I intend to use this service; and (3) I would recommend this service to others (Berezowska et al., 2015).

Manipulation checks were conducted using semantic differential scales ranging from immediate to delayed or illness prevention to health promotion and showed that the temporal distance and health outcome framing manipulations operated as intended. More specifically, there was a significant effect of temporal distance on the extent to which participants perceived the outcomes of the personalized nutrition service as immediate $(M=2.96, S E=.11)$ or delayed $(M=4.10, S E=.11), F(1,234)=48.61, p<.001$. Furthermore, there was a significant effect of health outcome framing on the extent to which participants perceived the personalized nutrition service to focus on illness prevention $(M=1.91, S E=.11)$ or health promotion $(M=3.73, S E=.11), \quad F(1$, $234)=130.14, p<.001$. The manipulation check of the regulatory focus manipulation conducted at the end of the experiment used a semantic differential scale from promoting positive to preventing negative outcomes did not show significant effects, $F(1$, $234)=1.59, p=.21$.

\section{Procedure}

Participants were welcomed into a classroom and seated at one of the available computers. Participants were told they would participate in a study consisting of several parts. The first part had an unrelated topic. In the second part, participants were randomly assigned to one of the two regulatory focus conditions. In the third part, participants were randomly presented with one of the four personalized nutrition service flyers ${ }^{2}$ and stated their intention to adopt the service that it described. Finally, participants reported their gender, age, and field of study. Participants received a snack to compensate their effort.

\footnotetext{
${ }^{2}$ Participants were also shown a second personalized nutrition service flyer, but as there were indications that the evaluation of the second flyer was influenced by the evaluation of the first one, evaluations of the second flyer were excluded from the analysis. Flyer 2 was introduced after the full completion of all measures related to Flyer $I$.
} 


\section{Results}

A factorial ANOVA showed a significant overall effect, $F(7,228)=3.20, p<.01$, partial $\eta^{2}=.09$. No main effect of temporal distance, $F(1,228)=0.71, p=.40$, partial $\eta^{2}<.01$, health outcome framing, $F(1,228)=2.09, p=.15$, partial $\eta^{2}=.01$, or regulatory focus, $F$ $(1,228)=0.70, p=.40$, partial $\eta^{2}<.01$, on adoption intention was found.

There was a significant interaction effect of regulatory focus and temporal distance on adoption intention, $F(1,228)=12.31, p=.001$, partial $\eta^{2}=.05$. Simple-effects analyses showed that prevention-focused participants had a higher adoption intention when health outcomes were immediate $(M=3.49, S E=.21)$ instead of delayed $(M=2.63$, $S E=.20), F(1,228)=9.25, p=.003$, partial $\eta^{2}=.04$. For promotion-focused participants, a trend towards higher adoption intention for delayed $(M=3.49, S E=.21)$ instead of immediate health outcomes was found $(M=2.96, S E=.19), F(1,228)=3.63$, $p=.058$, partial $\eta^{2}=.02$. The two-way interactions between regulatory focus and health outcome framing, $F(1,228)=2.84, p=.093$, partial $\eta^{2}=.01$, or temporal distance and health outcome framing, $F(1,228)=0.01, p=.91$, partial $\eta^{2}<.01$, were not significant.

There was a significant three-way interaction between temporal distance, health outcome framing, and regulatory focus, $F(1,228)=5.10, p=.025$, partial $\eta^{2}=.02$ (Figure 1). Simple-effects analyses were used to interpret the two-way interaction between regulatory focus and temporal distance for different health outcome framings. Prevent illness frame participants with a prevention focus were more likely to adopt a personalized nutrition service when health outcomes were immediate $(M=3.68$, $S E=.32)$ instead of delayed $(M=2.39, S E=.27), F(1,228)=9.62, p=.002$, partial $\eta^{2}=.04$. Participants with a promotion focus, on the other hand, were more likely to adopt a personalized nutrition service when health outcomes were delayed $(M=4.04$, $S E=.30)$ instead of immediate $(M=3.04, S E=.25), F(1,228)=6.67, p=.010$, partial $\eta^{2}=.03$. For the promote health frame, the interaction between regulatory focus and temporal distance was not significant $\left(F ' s<1.3\right.$, all, partial $\left.\eta^{2}<.01\right)$. Appendix S1 provides an overview of the observed means and standard deviations.

\section{Discussion}

Study 1 supports the expectation that prevention-focused individuals are more likely to prioritize health outcomes in the present, while promotion-focused individuals are more likely to prioritize health outcomes in the future. This difference between prevention- and promotion-focused individuals is, however, nullified when health outcomes are framed in

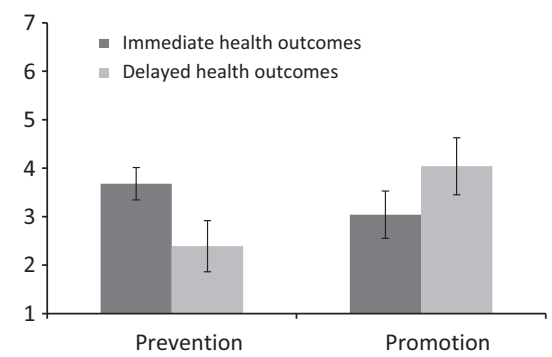

(a) Prevent illness frame

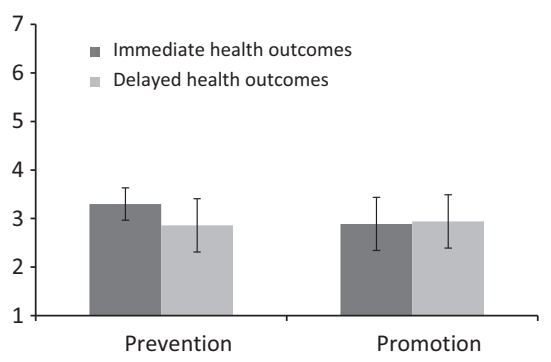

(b) Promote health frame

Figure I. Three-way interaction between temporal distance, health outcome framing, and regulatory focus. 
terms of health promotion instead of illness prevention. When interpreting the findings of Study 1, a reason for caution is the non-significant result of the regulatory focus manipulation check. However, as we used a well-established procedure and did find results that align with our hypotheses, we argue that the ineffectiveness of the manipulation check is likely to be caused by the extinction of the effect over the time span of the experiment. More specifically, it may be that the manipulation either worked for a short period or that participants were able to fulfil their motivational goal (preventing negative or promoting positive outcomes) by selecting a service. The intention measure contained a 'recommend to others' item that only seems indirectly relevant to the adoption of a service. However, as this item showed high internal consistency with the other items (indicated by Cronbach's $\alpha=.89$ ), it was decided to retain the item. Hence, the findings of Study 1 provide sufficient ground to investigate whether the effect of temporal distance, health outcome framing, and regulatory focus on adoption intention is mediated by individuals' perceptions of privacy risk and personalization benefit. Study 2, therefore, aims to replicate the results of Study 1 and in addition extends the research with privacy risk and personalization benefit perceptions as mediators.

\section{STUDY 2}

\section{Methods}

Study 2 was identical to Study 1, with the exception that the adoption intention items were followed by measures of perceived personalization benefit and perceived privacy risk (Table 1). Participants were 242 students aged between 16 and 31 years $(M=20.8$, $S D=1.72$ ), of whom $27.7 \%$ was male. Sample size was based on $80 \%$ power to detect a medium to large effects in the three way interaction. Data were collected late spring 2015. Mediation effects were tested using PROCESS for SPSS (Hayes, 2013) with a bias-corrected bootstrap estimation for 5,000 samples and a 95\% confidence interval.

\section{Results}

\section{Adoption intention}

A factorial ANOVA showed a significant overall effect, $F(7,234)=2.06, p<.05$, partial $\eta^{2}=.06$. A factorial ANOVA with adoption intention predicted by temporal distance, health outcome framing, and regulatory focus showed a significant main effect of health outcome framing. Adoption intention was higher for the prevent illness frame $(M=3.74$, $S E=.15)$ than for the promote health frame $(M=3.25, S E=.14), F(1,234)=5.63$, $p=.019$, partial $\eta^{2}=.02$. There was no main effect of regulatory focus, $F(1,234)=0.18$, $p=.67$, or temporal distance, $F(1,234)=2.45, p=.12$, on adoption intention.

Replicating Study 1, there was a significant interaction effect of regulatory focus and temporal distance on adoption intention, $F(1,234)=4.24, p=.041$, partial $\eta^{2}=.02$ (Figure 2). Simple-effects analysis confirmed the effects found in Study 1. For preventionfocused participants, adoption intention was higher when health outcomes were immediate $(M=3.83, S E=.21)$ instead of delayed $(M=3.08, \quad S E=.19), \quad F(1$, $234)=6.70, p=.010$, partial $\eta^{2}=.03$. The effect of temporal distance on adoption intention was not significant for promotion-focused participants, $F(1,234)=0.119$, $p=.731$, partial $\eta^{2}<.01$. None of the other two- or three-way interactions were significant (all $F$ 's $<0.8, p$ 's $>.35$, partial $\eta^{2}$ 's $<.01$ ). 
Table I. Measures Study 2

\begin{tabular}{|c|c|c|c|c|}
\hline Construct & Question & Items & Anchors & $\begin{array}{c}\text { Cronbach's } \\
\text { alpha }\end{array}$ \\
\hline $\begin{array}{l}\text { Adoption } \\
\text { intention }\end{array}$ & & $\begin{array}{l}\text { - I would consider using } \\
\text { this service } \\
\text { - I intend to use this service } \\
\text { - I would recommend } \\
\text { this service to others }\end{array}$ & $\begin{array}{l}\text { I = 'strongly } \\
\text { disagree' } \\
\text { to } 7=\text { 'strongly } \\
\text { agree' }\end{array}$ & .89 \\
\hline $\begin{array}{l}\text { Personalization } \\
\text { benefit }\end{array}$ & $\begin{array}{l}\text { Compared to } \\
\text { general } \\
\text { nutrition } \\
\text { advice, this } \\
\text { service offers } \\
\text { me nutrition } \\
\text { advice that is }\end{array}$ & $\begin{array}{l}\text { - More accurately tailored } \\
\text { to my health needs } \\
\text { - More relevant for } \\
\text { my health } \\
\text { - More beneficial for } \\
\text { my health }\end{array}$ & $\begin{array}{l}\text { I = 'strongly } \\
\text { disagree' } \\
\text { to } 7=\text { 'strongly } \\
\text { agree' }\end{array}$ & .83 \\
\hline Privacy risk & $\begin{array}{l}\text { I think that using } \\
\text { this service }\end{array}$ & $\begin{array}{l}\text { - Involves many } \\
\text { privacy-related risks } \\
\text { - Is a threat to my privacy } \\
\text { - Creates a high risk } \\
\text { for the loss of my privacy }\end{array}$ & $\begin{array}{l}\text { I = 'strongly } \\
\text { disagree' } \\
\text { to } 7=\text { 'strongly } \\
\text { agree' }\end{array}$ & .90 \\
\hline
\end{tabular}

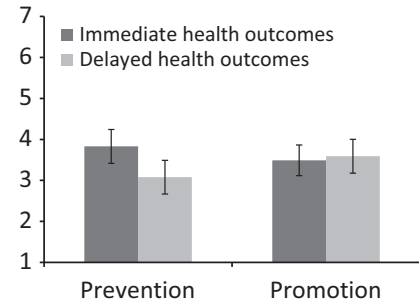

(a) Adoption

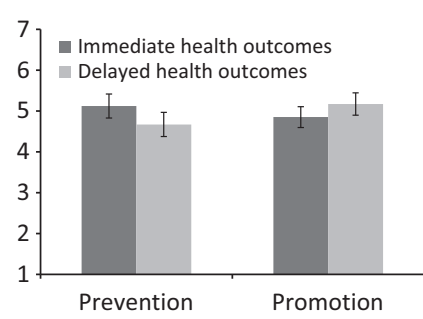

(b) Personalisation benefit

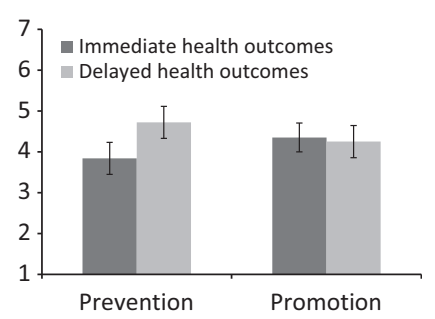

(c) Privacy risk

Figure 2. Interaction between regulatory focus and temporal distance for adoption intention, personalization benefit, and privacy risk.

\section{Personalization benefit}

A factorial ANOVA with perceived personalization benefit predicted by temporal distance, health outcome framing, and regulatory focus showed a significant main effect of health outcome framing. Benefit perception was higher for the prevent illness frame $(M=5.10, S E=.10)$ than for the promote health frame $(M=4.80, S E=.10), F(1$, $234)=4.40, p=.037$, partial $\eta^{2}=.02$. There was no main effect of regulatory focus, $F(1$, $234)=0.61, p=.44$, partial $\eta^{2}=<.01$, or temporal distance, $F(1,234)=0.23, p=.63$, partial $\eta^{2}=<.01$, on perceived personalization benefit.

There was a significant interaction effect of regulatory focus and temporal distance on perceived personalization benefit, $F(1,234)=7.39, p=.007$, partial $\eta^{2}=.03$. Simpleeffects analyses showed that prevention-focused participants had a higher perception of personalization benefit when health outcomes were immediate $(M=5.12, S E=.15)$ instead of delayed $(M=4.67, S E=.13), F(1,234)=5.21, p=.023$, partial $\eta^{2}=.02$. The effect of temporal distance on perceived personalization benefit was not significant for promotion-focused participants, $F(1,234)=2.46, p=.118$, partial $\eta^{2}=.01$. None of the 
other two- or three-way interactions were significant (all $F$ 's $<2.7$, $p$ 's $>.10$, partial $\left.\eta^{2}, \mathrm{~s}<.012\right)$.

\section{Privacy risk}

A factorial ANOVA where perceived privacy risk was predicted by temporal distance, health outcome framing, and regulatory focus showed a significant main effect of temporal distance. Risk perception was lower when health outcomes were immediate $(M=4.10, S E=.14)$ instead of delayed $(M=4.48, S E=.13), F(1,234)=4.07, p=.045$, partial $\eta^{2}=.02$. There was no main effect of regulatory focus, $F(1,234)=0.01, p=.91$, partial $\eta^{2}<.01$, or health outcome framing, $F(1,234)=0.0, p=.97$, partial $\eta^{2}<.01$, on perceived privacy risk.

There was a significant interaction effect of regulatory focus and temporal distance on perceived privacy risk, $F(1,234)=6.62, p=.011$, partial $\eta^{2}=.03$. Simple-effects analyses showed that prevention-focused participants had a lower perception of privacy risk when health outcomes were immediate $(M=3.84, S E=.20)$ instead of delayed $(M=4.72, S E=.18), F(1,234)=10.74, p=.001$, partial $\eta^{2}=.04$. The effect of temporal distance on perceived privacy risk was not significant for promotion-focused participants, $F(1,234)=0.15, p=.697$ partial $\eta^{2}<.01$. None of the other two- or threeway interactions were significant (all $F$ 's $<0.7$, $p$ 's $>.79$, partial $\eta^{2}$ 's $<.01$ ).

\section{Mediation analysis}

A mediation analysis was conducted to investigate whether significant effects of health outcome framing and interaction between regulatory focus and temporal distance on adoption intention were mediated by perceptions of privacy risk and/or personalization benefit. Perceived personalization benefit $(b=0.71, t=8.97, p<.001)$ determined adoption intention $\left(R^{2}=0.26\right)$. Perceived privacy risk did not determine $(b=-0.09$, $t=-1.51, p=.13$ ) adoption intention.

The main effect of health outcome framing on adoption intention was fully mediated by perceived personalization benefit. The direct effect of health outcome framing on adoption intention was not significant $(b=-0.14, p=.12)$. The indirect effect of health outcome framing on adoption intention through benefit perception was $b=-0.11$ (95\% CI $[-0.21,-0.02])$, with a moderate effect size of $\kappa^{2}=.08(95 \%$ CI $[0.02,0.14]){ }^{3}$

The effect of the interaction between regulatory focus and temporal distance on adoption intention was also fully mediated by perceived personalization benefit. The direct effect of the interaction between regulatory focus and temporal distance on adoption intention was not significant at $b=0.07, p=.45$. The indirect effect of the interaction between regulatory focus and temporal distance on adoption intention was $b=0.15$ (95\% CI $[0.06,0.25])$, with a moderate effect size of $\kappa^{2}=.10$ (95\% CI [0.04, 0.17]).

\section{Discussion}

Study 2 shows that the interaction between regulatory focus and temporal distance determines not only adoption intention, but also perceived personalization benefit and

\footnotetext{
${ }^{3}$ As $\kappa^{2}$ can only be estimated for a single indirect effect paths through risk perception were omitted. Separate analyses with parallel mediators confirmed the indirect effects through risk perception were not significant for health outcome framing $\mathrm{b}<-0.01$ (95\% Cl $[-0.03,0.03])$, nor regulatory focus temporal distance interaction $\mathrm{b}=0.02(95 \% \mathrm{Cl}[-0.01,0.08])$.
} 
perceived privacy risk, which replicates and extends the results of Study 1 . The three-way interaction from study 1 (partial $\eta^{2}=.02$ ) was not replicated in Study 2 (partial $\left.\eta^{2}=.002\right)$. Furthermore, Study 2 showed a main effect of health outcome framing on adoption intention (partial $\eta^{2}=.02$ ) where Study 1 did not (partial $\eta^{2}=.01$ ). The inconsistencies in the findings of Study 1 and Study 2 cannot be explained by experimental differences as risk and benefit perception was assessed after measuring adoption intention.

Temporal distance had a significant effect on perceived privacy risk but not on perceived personalization benefit, which provides partial support for our expectations. However, rather than decrease over time, perceptions of privacy risk were higher when temporal distance was high. This finding may have occurred due to the fact that privacy risk perceptions depend on the extent to which individuals feel in control over their personal information (Phelps, Nowak, \& Ferrell, 2000), and information control is likely to decrease as time passes. Against expectation, perceptions of privacy risk were not a mediator.

\section{GENERAL DISCUSSION}

Two experiments confirmed that adoption intention is determined by the interaction between regulatory focus and temporal distance. In line with Hypothesis 1a, individuals who strived for safety and security (i.e., prevention focus) preferred to adopt a personalized nutrition service that offers immediate rather than delayed health outcomes. Rather than increase when provided health outcomes are delayed instead of immediate (Hypothesis 1b), the adoption intention of individuals who strived for accomplishment and advancement (i.e., promotion focus) remained unaffected by temporal distance.

Mediated through perceived personalization benefit, in line with Hypothesis 2, the interaction between regulatory focus and temporal distance affected individuals' intention to adopt a personalized nutrition service. Prevention-focused individuals had higher perceptions of personalization benefit when nutritional recommendations offered immediate rather than delayed health outcomes (Hypothesis 4a). However, rather than increase when provided health outcomes are delayed instead of immediate (Hypothesis $4 \mathrm{~b}$ ), for promotion-focused individuals temporal distance did not have an effect on perceived personalization benefit. The results align with findings that behavioural motivation moderates the relationship between perceived personalization benefit and its antecedents (Berezowska, Fischer, \& Van Trijp, 2017). The current study extends this by demonstrating that not only the reason $w h y$ individuals are motivated to adopt services but also what they want to achieve through adoption influences individuals' perceptions of personalization benefit.

Prevention-focused individuals had lower perceptions of privacy risk when nutritional recommendations offered immediate rather than delayed health outcomes (Hypothesis 5a). However, rather than decrease when provided health outcomes are delayed instead of immediate (Hypothesis 5b), in the case of promotion-focused individuals temporal distance did not influence perceived privacy risk. In contrast to Hypothesis 3, perceived privacy risk was not a significant mediator in the cognitive process as perceived privacy risk did not affect adoption intention. Privacy concern was spontaneously voiced in other studies on the topic (Berezowska et al., 2014), suggesting perceived privacy risk should be relevant. To create a research setting that closely fits the real world, stimulus materials highlighted positive health outcomes of personalized nutrition, which may explain why perceived privacy risk did not contribute to adoption intention. Considering that 
individuals often ignore privacy risks when benefits are present (Belanger \& Crossler, 2011; Pavlou, 2011; Smith, Dinev, \& Xu, 2011), the salience of the positive health outcomes may have downplayed the importance of privacy risk. When benefits are less prominent, it may be that perceived privacy risk will affect adoption. Future research seems warranted to determine to what extent and in which circumstances perceived privacy risk matters for these types of services.

The finding that promotion-focused individuals were insensitive to temporal distance could be further understood by drawing on construal level theory (Trope \& Liberman, 2010). Construal level theory proposes that individuals reason about objects and events from the perspective of either a low (i.e., emphasis is on details) or high (i.e., emphasis is on the bigger picture) construal level. Compared to low construal, individuals who reason from a high construal mindset are more likely to engage in global information processing (Forster \& Higgins, 2005) that revolves around the desirability of behavioural outcomes (Sagristano, Trope, \& Liberman, 2002). As a promotion focus is associated with high construal reasoning (Lee, Keller, \& Sternthal, 2010), it is likely that promotion-focused individuals paid attention to whether the adoption of a personalized nutrition service will result in positive health outcomes at all rather than to when the health outcomes will occur. Future research should validate this explanation by showing that high construal reasoning leads to similar outcomes as promotion-focused regulatory orientations.

The current study did not find support for the regulatory fit hypothesis (Hypothesis 6), which predicts an increase in adoption intention when the framing of a health message matches individuals' regulatory orientation (Higgins, 2000). The results of Study 1 did show that the interaction between regulatory focus and temporal distance is affected by framing. Prevention-focused individuals preferred immediate and promotion-focused individuals preferred delayed health outcomes, but only when the health outcomes were framed as illness prevention, and not health promotion. Although these results suggest that health promotion frames allow to align temporal distance with regulatory focus, the results of Study 2 do not replicate this suggestion and instead show that health promotion frames reduce both benefits perceptions and adoption intention. Thus, similar to other studies (Latimer et al., 2008; Martinez, Duncan, Rivers, Latimer, \& Salovey, 2013; Pfeffer, 2013), the current paper shows that a regulatory fit effect towards acceptance of delayed versus immediate effects is difficult to prove. The current findings, therefore, align with the idea that differences between loss versus gain frames may be less important than often assumed (Van't Riet et al., 2016), as these differences may be subject to subtle effects of other interacting variables. The consistency in main and two interaction effects across the two studies suggests that there is a stable mechanism which steers the adoption intention of personalized nutrition services. However, its effect is small and therefore not of immediate practical relevance. To increase practical relevance, it may be worthwhile for future research to investigate additional framing effects or identify moderating variables such a health motivation.

Although this study aimed to test theoretical rather than population relevant differences, the sample's relative homogeneity in term of age and education level (i.e., student sample) may warrant some caution with regard to the generalization of our findings. For instance, prior research shows that young adults are more inclined to disclose personal information (Nosko, Wood, \& Molema, 2010) and consequently may be less sensitive to potential privacy risks. Furthermore, when thinking about the future adolescents are mainly concerned with relatively short-term outcomes related to education and career (Nurmi, 1991), which might have downplayed the importance of future health outcomes. Considering the potential limitations resulting from the use of a 
student sample, we recommend future research to confirm the present findings with a more representative sample.

The current study investigated the intention to adopt personalized nutrition services, which in a diet context is expected to explain about 20\% of actual behaviour (McEachan, Conner, Taylor, \& Lawton, 2011). Adoption intention is, however, only the first step towards a healthier diet. Future research should show to what extent the findings of this study are reflected both in adopting a personalized nutrition service and a healthy diet.

\section{Conclusion}

This study advances health-related theory by showing how the motivation that drives individuals' health goals affects their preference for short- or long-term health outcomes. Individuals who want to avoid disease prefer short-term health outcomes, while for individuals who want to optimize health the timing of health outcomes seems irrelevant. From a practical point of view, these findings imply that to stimulate the adoption of personalized nutrition services, these should be designed in a way that places their health effects as close in time as possible.

\section{Conflict of interest}

All authors declare no conflict of interest.

\section{References}

Belanger, F., \& Crossler, R. E. (2011). Privacy in the digital age: A review of information privacy research in information systems. MIS Quarterly, 35, 1017-1041.

Berezowska, A., Fischer, A. R. H., Ronteltap, A., Kuznesof, S., Macready, A., Fallaize, R., \& Van Trijp, H. C. M. (2014). Understanding consumer evaluations of personalised nutrition services in terms of the privacy calculus: A qualitative study. Public Health Genomics, 17(3), 127-140. https:// doi.org/10.1159/000358851

Berezowska, A., Fischer, A. R. H., Ronteltap, A., Van der Lans, I. A., \& Van Trijp, H. C. M. (2015). Consumer adoption of personalised nutrition services from the perspective of a risk-benefit trade-off. Genes and Nutrition, 10(6), 2-14. https://doi.org/10.1007/s12263-015-0478-y

Berezowska, A., Fischer, A. R. H., \& Van Trijp, H. C. M. (2017). The moderating effect of motivation on health related decision-making. Psychology \& Health, 32, 665-685. https://doi.org/10.1080/ 08870446.2017 .1293055

Bouwman, L. I., te Molder, H., Koelen, M. M., \& van Woerkum, C. M. J. (2009). I eat healthfully but I am not a freak. Consumers' everyday life perspective on healthful eating. Appetite, 53, 390-398. https://doi.org/10.1016/j.appet.2009.08.005

Cesario, J., Grant, H., \& Higgins, E. T. (2004). Regulatory fit and persuasion: Transfer from "feeling right". Journal of Personality and Social Psychology, 86, 388-404. https://doi.org/10.1037/ 0022-3514.86.3.388

Chapman, G. B., \& Elstein, A. S. (1995). Valuing the future temporal discounting of health and money. Medical Decision Making, 15, 373-386. https://doi.org/10.1177/0272989x 9501500408

Cohen, J. (1992). A power primer. Psychological Bulletin, 112(1), 155-159.

Eyal, T., Liberman, N., Trope, Y., \& Walther, E. (2004). The pros and cons of temporally near and distant action. Journal of Personality and Social Psychology, 86, 781-795. https://doi.org/10. 1037/0022-3514.86.6.781

Forster, J., \& Higgins, E. T. (2005). How global versus local perception fits regulatory focus. Psychological Science, 16, 631-636. https://doi.org/10.1111/j.1467-9280.2005.01586.x 
Gibney, M. J., \& Walsh, M. C. (2013). The future direction of personalised nutrition: My diet, my phenotype, my genes. Proceedings of the Nutrition Society, 72, 219-225. https://doi.org/10. $1017 /$ s0029665112003436

Gomez, P., Borges, A., \& Pechmann, C. (2013). Avoiding poor health or approaching good health: Does it matter? The conceptualization, measurement, and consequences of health regulatory focus. Journal of Consumer Psychology, 23, 451-463. https://doi.org/10.1016/j.jcps.2013.02.001

Hayes, A. F. (2013). Introduction to mediation, moderation, and conditional process analysis: A regression-based approach. New York, NY: Guilford Press.

Higgins, E. T. (1997). Beyond pleasure and pain. American Psychologist, 52, 1280-1300.

Higgins, E. T. (2000). Making a good decision: Value from fit. American Psychologist, 55, $1217-$ 1230.

Hong, J., \& Lee, A. Y. (2008). Be fit and be strong: Mastering self-regulation through regulatory fit. Journal of Consumer Research, 34, 682-695. https://doi.org/10.1086/521902

Latimer, A. E., Rivers, S. E., Rench, T. A., Katulak, N. A., Hicks, A., Hodorowski, J. K., ... Salovey, P. (2008). A field experiment testing the utility of regulatory fit messages for promoting physical activity. Journal of Experimental Social Psychology, 44, 826-832. https://doi.org/10.1016/j.je sp.2007.07.013

Lee, A. Y., Keller, P. A., \& Sternthal, B. (2010). Value from regulatory construal fit: The persuasive impact of fit between consumer goals and message concreteness. Journal of Consumer Research, 36, 735-747. https://doi.org/10.1086/605591

Lockwood, P., Jordan, C. H., \& Kunda, Z. (2002). Motivation by positive or negative role models: Regulatory focus determines who will best inspire us. Journal of Personality and Social Psychology, 83, 854-864. https://doi.org/10.1037//0022-3514.83.4.854

Ludolph, R., \& Schulz, P. J. (2015). Does regulatory fit lead to more effective health communication? A systematic review. Social Science \& Medicine, 128, 142-150. https://doi.org/10.1016/j.socsc imed.2015.01.021

Martinez, J. L., Duncan, L. R., Rivers, S. E., Latimer, A. E., \& Salovey, P. (2013). Examining the use of message tailoring to promote physical activity among medically underserved adults. Journal of Health Psychology, 18, 470-476. https://doi.org/10.1177/1359105312445798

McEachan, R. R. C., Conner, M., Taylor, N. J., \& Lawton, R. J. (2011). Prospective prediction of health-related behaviours with the Theory of Planned Behaviour: A meta-analysis. Health Psychology Review, 5(2), 97-144. https://doi.org/10.1080/17437199.2010.521684

Mogilner, C., Aaker, J. L., \& Pennington, G. L. (2008). Time will tell: The distant appeal of promotion and imminent appeal of prevention. Journal of Consumer Research, 34, 670-681. https://doi. org/10.1086/521901

Motyka, S., Grewal, D., Puccinelli, N. M., Roggeveen, A. L., Avnet, T., Daryanto, A., ... Wetzels, M. (2014). Regulatory fit: A meta-analytic synthesis. Journal of Consumer Psychology, 24, 394410. https://doi.org/10.1016/j.jcps.2013.11.004

Nosko, A., Wood, E., \& Molema, S. (2010). All about me: Disclosure in online social networking profiles: The case of facebook. Computers in Human Behavior, 26, 406-418. https://doi.org/ 10.1016/j.chb.2009.11.012

Nurmi, J.-E. (1991). How do adolescents see their future? A review of the development of future orientation and planning. Developmental Review, 11(1), 1-59. https://doi.org/10.1016/02732297(91)90002-6

Pavlou, P. A. (2011). State of the information privacy literature: Where are we now and where should we go? MIS Quarterly, 35, 977-988.

Pennington, G. L., \& Roese, N. J. (2003). Regulatory focus and temporal distance. Journal of Experimental Social Psychology, 39, 563-576. https://doi.org/10.1016/s0022-1031(03)00058-1

Pfeffer, I. (2013). Regulatory fit messages and physical activity motivation. Journal of Sport and Exercise Psychology, 35(2), 119-131.

Phelps, J., Nowak, G., \& Ferrell, E. (2000). Privacy concerns and consumer willingness to provide personal information. Journal of Public Policy \& Marketing, 19(1), 27-41. https://doi.org/10. 1509/jppm.19.1.27.16941 
Poínhos, R., van der Lans, I. A., Rankin, A., Fischer, A. R., Bunting, B., Kuznesof, S., . . Frewer, L. J. (2014). Psychological determinants of consumer acceptance of personalised nutrition in 9 European countries. PLoS One, 9(10), https://doi.org/10.1371/journal.pone.0110614

Ronteltap, A., Van Trijp, H., Berezowska, A., \& Goossens, J. (2013). Nutrigenomics-based personalised nutritional advice: In search of a business model? Genes and Nutrition, 8, 153163. https://doi.org/10.1007/s12263-012-0308-4

Ronteltap, A., van Trijp, J. C. M., \& Renes, R. J. (2007). Expert views on critical success and failure factors for nutrigenomics. Trends in Food Science and Technology, 18(4), 189-200. https://doi. org/10.1016/j.tifs.2006.12.007

Sagristano, M. D., Trope, Y., \& Liberman, N. (2002). Time-dependent gambling: Odds now, money later. Journal of Experimental Psychology-General, 131, 364-376. https://doi.org/10.1037// 0096-3445.131.3.364

Smith, H. J., Dinev, T., \& Xu, H. (2011). Information privacy research: An interdisciplinary review. MIS Quarterly, 35, 989-1015.

Spiegel, S., Grant-Pillow, H., \& Higgins, E. T. (2004). How regulatory fit enhances motivational strength during goal pursuit. European Journal of Social Psychology, 34(1), 39-54. https://doi. org/10.1002/ejsp.180

Steinhart, Y., Mazursky, D., \& Kamins, M. A. (2013). The "temporal-processing-fit effect": The interplay between regulatory state, temporal distance, and construal levels. Social Cognition, 31, 315-335.

Story, G. W., Vlaev, I., Seymour, B., Darzi, A., \& Dolan, R. J. (2014). Does temporal discounting explain unhealthy behavior? A systematic review and reinforcement learning perspective. Frontiers in Behavioral Neuroscience, 8, 1-20. https://doi.org/10.3389/fnbeh.2014.00076

Trope, Y., \& Liberman, N. (2010). Construal-level theory of psychological distance. Psychological Review, 117, 440-463. https://doi.org/10.1037/a0018963

Van't Riet, J., Cox, A. D., Cox, D., Zimet, G. D., De Bruijn, G.-J., Van den Putte, B., . . Ruiter, R. A. (2016). Does perceived risk influence the effects of message framing? Revisiting the link between prospect theory and message framing. Health Psychology Review, 10, 447-459. https://doi.org/10.1080/08870446.2014.896916

Wallace, C., \& Chen, G. (2006). A multilevel integration of personality, climate, self-regulation, and performance. Personnel Psychology, 59, 529-557. https://doi.org/10.1111/j.1744-6570.2006. 00046.x

Werth, L., \& Forster, J. (2007). How regulatory focus influences consumer behavior. European Journal of Social Psychology, 37(1), 33-51. https://doi.org/10.1002/ejsp.343

Received 2 September 2016; revised version received 22 July 2017

\section{Supporting Information}

The following supporting information may be found in the online edition of the article:

Appendix S1. Observed means and standard deviations for Study 1 and Study 2. 


\section{Appendix A: Content of the personalized nutrition service flyers}

\begin{tabular}{|c|c|c|}
\hline & Immediate health outcomes & Delayed health outcomes \\
\hline \multirow[t]{3}{*}{ Illness prevention } & $\begin{array}{l}\text { Personalize your diet and prevent feeling } \\
\text { drained in the summer! } \\
\text { Our qualified dietitians provide you } \\
\text { with tailored nutrition and exercise } \\
\text { advice that is designed for you and you } \\
\text { only. This tailored advice helps you to } \\
\text { prevent fatigue. } \\
\text { How? } \\
\text { To prevent fatigue, our dietitians use } \\
\text { highly advanced techniques, among } \\
\text { which DNA analysis. Analysing your } \\
\text { DNA allows us to identify which } \\
\text { exact nutrients you need to } \\
\text { minimize the likelihood of fatigue. } \\
\text { Scientific research shows that } \\
\text { nutrition and exercise advice } \\
\text { tailored specifically to your DNA is } \\
\text { significantly more effective than } \\
\text { general advice that can be found on } \\
\text { the Internet! }\end{array}$ & $\begin{array}{l}\text { Personalize your diet and prevent health } \\
\text { problems after you're } 50 \text { ! } \\
\text { Our qualified dietitians provide you } \\
\text { with tailored nutrition and exercise } \\
\text { advice that is designed for you and you } \\
\text { only. This tailored advice helps you to } \\
\text { prevent health loss as you get older. } \\
\text { How? } \\
\text { To prevent health loss, our dietitians } \\
\text { use highly advanced techniques, } \\
\text { among which DNA analysis. } \\
\text { Analysing your DNA allows us to } \\
\text { identify which exact nutrients you } \\
\text { need to make sure that your health } \\
\text { remains optimal. Scientific research } \\
\text { shows that nutrition and exercise } \\
\text { advice tailored specifically to your } \\
\text { DNA is significantly more effective } \\
\text { than general advice that can be found } \\
\text { on the Internet! }\end{array}$ \\
\hline & $\begin{array}{l}\text { Costs? } \\
\text { The costs of the analysis, advice, and } \\
\text { coaching are reimbursed by your } \\
\text { health insurance company. }\end{array}$ & $\begin{array}{l}\text { Costs? } \\
\text { The costs of the analysis, advice, and } \\
\text { coaching are reimbursed by your } \\
\text { health insurance company. }\end{array}$ \\
\hline & $\begin{array}{l}\text { Do you want to prevent feeling drained in } \\
\text { the summer? }\end{array}$ & $\begin{array}{l}\text { Do you want to prevent health problems } \\
\text { after you're } 50 \text { ? } \\
\text { Make an appointment on .... }\end{array}$ \\
\hline Health promotion & $\begin{array}{l}\text { Personalize your diet and start your summer } \\
\text { in an even better shape! } \\
\text { Our qualified dietitians provide you } \\
\text { with tailored nutrition and exercise } \\
\text { advice designed for you and you } \\
\text { only. This tailored advice helps } \\
\text { you to increase your energy } \\
\text { level. }\end{array}$ & $\begin{array}{l}\text { Personalize your diet and feel full of energy } \\
\text { after you're } 50 \text { ! } \\
\text { Our qualified dietitians provide you } \\
\text { with tailored nutrition and exercise } \\
\text { advice that is designed for you and } \\
\text { you only. This tailored advice helps } \\
\text { you to maintain your shape for many } \\
\text { years to come. }\end{array}$ \\
\hline & How? & How? \\
\hline & $\begin{array}{l}\text { To boost your energy, our dietitians } \\
\text { use highly advanced techniques, } \\
\text { among which DNA analysis. } \\
\text { Analysing your DNA allows us to } \\
\text { identify which exact } \\
\text { nutrients you need to enhance your } \\
\text { energy level. Scientific research } \\
\text { shows that nutrition and exercise }\end{array}$ & $\begin{array}{l}\text { To keep your shape in an optimal } \\
\text { state, our dietitians use highly } \\
\text { advanced techniques, among which } \\
\text { DNA analysis. Analysing your DNA } \\
\text { allows us to identify which exact } \\
\text { nutrients you need to maintain a } \\
\text { great shape, also in the future. } \\
\text { Scientific research shows that }\end{array}$ \\
\hline
\end{tabular}


Appendix A: ( Continued)

Immediate health outcomes

Delayed health outcomes

advice tailored specifically to your DNA is significantly more effective than general advice that can be found on the Internet!

Costs?

The costs of the analysis, advice, and coaching are reimbursed by your health insurance company.

Do you want to start your summer in an even better shape?

nutrition and exercise advice tailored specifically to your DNA is significantly more effective than general advice that can be found on the Internet!

Costs?

The costs of the analysis, advice, and coaching are reimbursed by your health insurance company.

Make an appointment on .... Make an appointment on ....
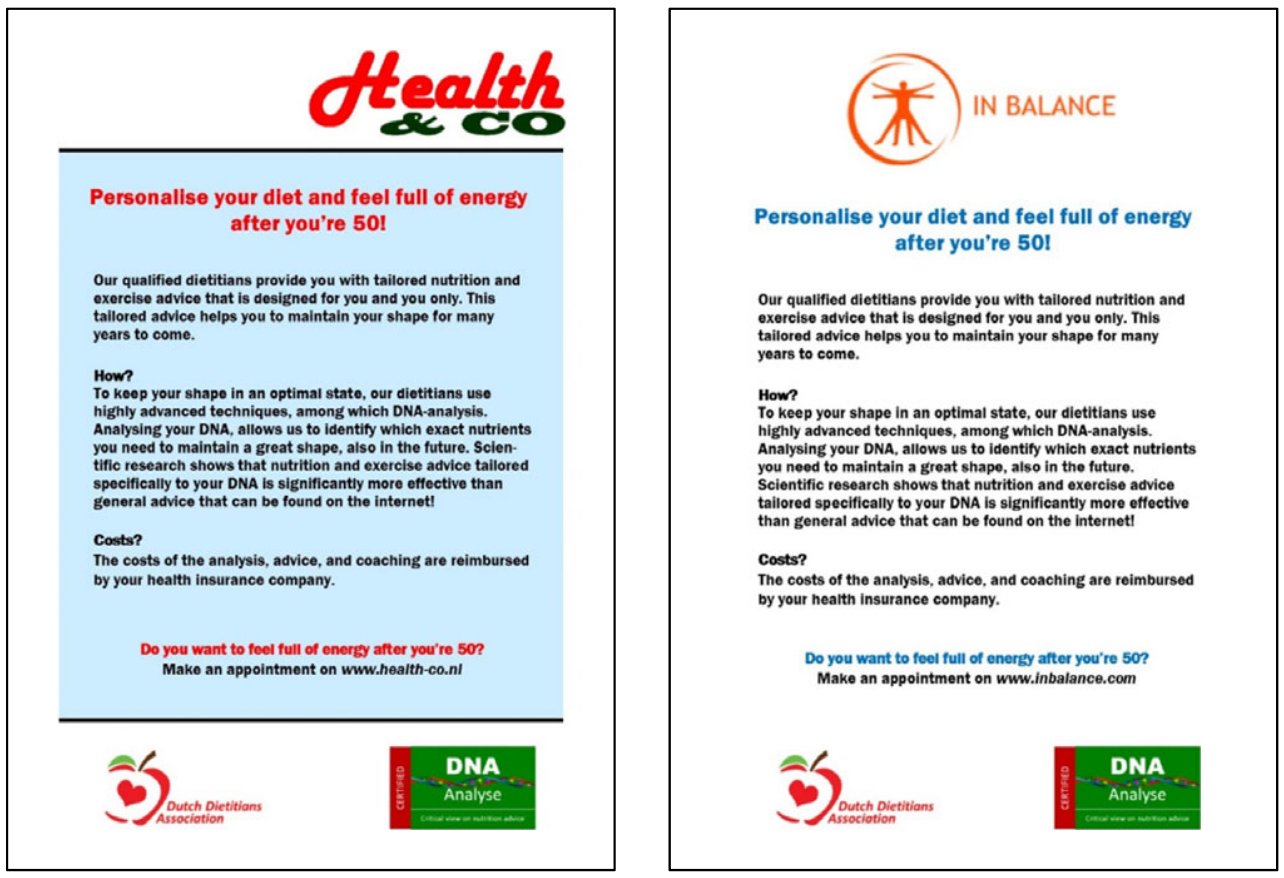

Appendix B: Layout of the personalized nutrition service flyers [Colour figure can be viewed at wileyonlinelibrary.com] 